\title{
TOTAL FACTOR PRODUCTIVITY AND CONVERGENCE: EVIDENCE FROM OLD AND NEW EU MEMBER COUNTRIES' BANKING SECTORS
}

\author{
Adnan Kasman', Saadet Kasman ${ }^{2}$, Duygu Ayhan ${ }^{3}$, Erdost Torun ${ }^{4}$ \\ 1,2 Department of Economics, Faculty of Business, Dokuz Eylul University, \\ 35160 Buca, Izmir, Turkey \\ ${ }^{3,4}$ Department of International Business and Trade, Faculty of Business, \\ Dokuz Eylul University, 35160 Buca, Izmir, Turkey \\ E-mails: 19adnan.kasman@deu.edu.tr (correspondingauthor); ${ }^{2}$ saadet.kasman@deu.edu.tr; \\ 3aduygu.ayhan@deu.edu.tr; ${ }^{4}$ erdost.torun@deu.edu.tr \\ Received 29 November 2011; accepted 06 June 2012
}

\begin{abstract}
This paper examines whether there has been convergence of total factor productivity levels across twenty-two EU member and three candidate countries following the process of legislative harmonization. The results indicate evidence of $\beta$-convergence and $\sigma$-convergence in productivity across sampled countries. The results further indicate that all sampled banking sectors seem to have experienced a significant productivity growth over the sample period. The productivity growth levels range from $3.1 \%$ to $15.6 \%$ and $6.8 \%$ to $19.5 \%$ in the old member and new member states, respectively. The geometric means considering all banking firms in the new member and candidate countries together reveal that banking sectors in these countries were more productive than those of in the old EU member countries. Overall, the evidence indicates that promoting merger and acquisition activities in the banking system (and hence supporting market driven consolidation of smaller banks) and enhancing the presence of foreign banks could increase competition and productivity in these banking systems.
\end{abstract}

Keywords: banking, productivity, convergence, integration, EU members, Malmquist.

Reference to this paper should be made as follows: Kasman, A.; Kasman, S.; Ayhan, D.; Torun, E. 2013. Total factor productivity and convergence: evidence from old and new EU member countries' banking sectors, Journal of Business Economics and Management 14(Supplement 1): S13-S35.

\section{Introduction}

The Central and Eastern European (CEE) countries have witnessed various institutional, regulatory and supervisory reforms, which radically transformed their financial systems. The formation of financial infrastructure has been a cornerstone in the transition process, which includes the establishment of a sound, stable and efficient banking system. The initial efforts of transformation to market economies in these countries were later 
reinforced by the goal of European Union (EU) membership ${ }^{1}$. However, the structural differences between the new and old EU member countries possessed great challenges, particularly in terms of catching up with the old EU member countries ${ }^{2}$. Significant efforts were directed towards improving the banking supervision regulative framework within the EU regulative system and the international standards of effective supervisions.

The main aim of this paper is to examine the impacts of this restructuring process on the productivity growth of the banking firms in twenty-two EU member and three candidate countries. Particularly, we investigate whether there has been convergence of total factor productivity growth levels across sampled countries following the process of legislative harmonization. Two major concepts of convergence, $\beta$-convergence and $\sigma$-convergence are used to test convergence in productivity. Recently, a few study analyzed convergence in bank profitability and efficiency for EU banking. Weill (2009) investigated whether financial integration has taken place in the European banking markets, by examining convergence in cost efficiency and measured cost efficiency of banks from ten old EU member countries. Mamatzakis et al. (2008), however, examined the cost and profit efficiency convergence across ten new EU member countries. Moreover, Goddard et al. (2013) investigated the convergence of bank profitability in eight EU member countries.

This study significantly differs from those of Weill (2009), Mamatzakis et al. (2008) and Goddard et al. (2013) in two respects: first, it includes both old and new EU member countries into the productivity (and/or efficiency) convergence analysis. Including both groups of countries in the analysis is essential since there was a significant dispersion of productivity and efficiency between the old and new member EU countries. Differences in the legal and economic environments could cause a productivity gap between two groups of countries. Hence, it is worthwhile to examine whether this gap has decreased over the sample period. Secondly, this paper also investigates the evolution of total factor productivity in the sampled countries. The profound transformation and deregulation process that has taken place in the new EU members together with the intensive process of European financial integration offer an opportunity to assess bank performance in comparison with that of the old EU members. The empirical evidence may help to analyze and compare the success or failure of policy implications in European banking system. While numerous studies have investigated the productivity of banking firms in European countries, most of the research focused on the productivity (and/or efficiency)

\footnotetext{
${ }^{1}$ In 2004, the eight Central and Eastern European transition countries (the Czech Republic, Estonia, Hungary, Latvia, Lithuania, Poland, the Slovak Republic, and Slovenia) and two market-economy countries (Malta and Cyprus) joined the European Union. Bulgaria and Romania joined the union in 2007 and Croatia in 2013. FRY Macedonia and Turkey hope to become members in the near future.

2 The banking systems in the developed EU member countries have also undergone significant regulatory changes in the last two decades due to the financial integration process. By eliminating restrictions on market entry and establishing minimum regulatory requirements across the EU banking markets, the largest integrated banking market in the world has been established. Moreover, monetary integration, particularly the introduction of Euro, opened a way for further deepening of the banking system integration.
} 
of banking firms in developed EU member countries. However, studies on the productivity of banking firms in the new EU member and candidate countries are very limited. Moreover, this paper is more comprehensive than the previous studies since it includes most of the EU member and the three candidate countries in the analysis.

\section{Previous studies on banking productivity in EU countries}

The literature on international comparisons of bank productivity has two distinct features. First, the number of existing studies on banking productivity is low, when compared with studies on banking efficiency ${ }^{3}$. Second, the number of cross-country studies on productivity is also low, when compared with the plethora of bank productivity studies confined to a single country. Table 1 provides an overview of the existing literature particularly dealing with bank productivity in European countries. Table 1 also provides information on the methodological approach used and input/output definitions adopted in the previous studies.

Among the international comparisons for EU banks, Chaffai et al. (2001) examined the banking productivity differences among the major countries of the Euroland (France, Germany, Italy and Spain) over the period 1993-1997. They defined bank inputs and outputs according to the value-added approach, and found that environmental conditions are significant in explaining the productivity gaps among countries. Casu et al. (2004) compare the competing methodologies (parametric and non-parametric approaches) to investigate productivity changes and its decomposition in the largest European banking markets (France, Germany, Italy, Spain, UK) over the period 1994-2000. They used stochastic frontier analysis (SFA) and data envelopment analysis (DEA) to estimate productivity changes and adopted intermediation approach for defining the outputs. Their results indicate that the competing methodologies do not give significantly different results while detecting the decomposition of productivity growth. There is an overall productivity growth for the sample countries, particularly for Spanish and Italian banks, and positive technological change lead to productivity growth in these two banking industries. Following the same sample countries and sample period, Casu and Girardone (2005) analyzed total factor productivity (TFP) estimates obtained with and without off-balance sheet activities. They used DEA to estimate TFP and defined bank inputs and outputs according to the intermediation approach. The results suggest that the exclusion of these non-traditional activities lead to lower productivity levels. In addition to this, the inclusion of these activities mostly influenced technological change rather than efficiency change.

\footnotetext{
${ }^{3}$ Many studies have investigated the efficiency of the European banking industries in recent years. Most of the studies in the efficiency literature analyze the impact of regulatory changes in the banking systems on the European bank efficiency. See for example, Bonin et al. (2003), Casu and Molyneux (2003), Fries and Taci (2005), Hasan and Marton (2003), Kasman (2005), Kasman and Yildirim (2006), Grigoran and Manole (2006), Matousek (2008), Stavarek (2006), Yildirim and Philippatos (2006), and Akin et al. (2013).
} 
Table 1. Literature on European banking productivity

\begin{tabular}{|c|c|c|c|}
\hline Authors & Country Sample & Approaches & Output/Input Definition \\
\hline $\begin{array}{l}\text { Pastor et al. } \\
\text { (1997) }\end{array}$ & $\begin{array}{l}\text { Austria, Belgium, France, } \\
\text { Germany, Italy, Spain, UK, } \\
\text { US }\end{array}$ & $\begin{array}{l}\text { Distance } \\
\text { Function }\end{array}$ & Value-added Approach \\
\hline Chaffai et al. (2001) & $\begin{array}{l}\text { France, Germany, Italy, } \\
\text { Spain }\end{array}$ & $\begin{array}{l}\text { Distance } \\
\text { Function }\end{array}$ & Value-added Approach \\
\hline Mörttinen (2002) & $\begin{array}{l}\text { Finland, France, Germany, } \\
\text { Italy, Sweden, UK }\end{array}$ & $\begin{array}{l}\text { Stochastic } \\
\text { Frontier } \\
\text { Analysis }\end{array}$ & User-cost Approach \\
\hline $\begin{array}{l}\text { Casu et al. } \\
\text { (2004) }\end{array}$ & $\begin{array}{l}\text { France, Germany, Italy, } \\
\text { Spain, UK }\end{array}$ & DEA & $\begin{array}{l}\text { Intermediation } \\
\text { Approach }\end{array}$ \\
\hline $\begin{array}{l}\text { Casu and Girardone } \\
(2005)\end{array}$ & $\begin{array}{l}\text { France, Germany, Italy, } \\
\text { Spain, UK }\end{array}$ & DEA & $\begin{array}{l}\text { Intermediation } \\
\text { Approach }\end{array}$ \\
\hline $\begin{array}{l}\text { Lozano-Vivas } \\
\text { and Pastor (2006) }\end{array}$ & 15 OECD countries & DEA & $\begin{array}{l}\text { Intermediation } \\
\text { Approach }\end{array}$ \\
\hline $\begin{array}{l}\text { Fiordelisi and } \\
\text { Molyneux (2010) }\end{array}$ & France, Germany, Italy, UK & DEA & Value-added Approach \\
\hline $\begin{array}{l}\text { Koutsomanoli- } \\
\text { Filippaki et al. } \\
(2009)\end{array}$ & CEE countries & $\begin{array}{l}\text { Distance } \\
\text { Function }\end{array}$ & $\begin{array}{l}\text { Intermediation } \\
\text { Approach }\end{array}$ \\
\hline $\begin{array}{l}\text { Grifell-Tatje } \\
\text { and Lovell (1997) }\end{array}$ & Spain & DEA & Value-added Approach \\
\hline $\begin{array}{l}\text { Ali and Gstach } \\
(2000)\end{array}$ & Austria & DEA & $\begin{array}{l}\text { Intermediation } \\
\text { Approach }\end{array}$ \\
\hline $\begin{array}{l}\text { Rebelo and Mendes } \\
(2000)\end{array}$ & Portugal & DEA & $\begin{array}{l}\text { Intermediation } \\
\text { Approach }\end{array}$ \\
\hline $\begin{array}{l}\text { Canhoto and } \\
\text { Dermine (2003) }\end{array}$ & Portugal & DEA & $\begin{array}{l}\text { Intermediation } \\
\text { Approach }\end{array}$ \\
\hline $\begin{array}{l}\text { Kumbhakar et al. } \\
\text { (2001) }\end{array}$ & Spain & $\begin{array}{l}\text { Stochastic } \\
\text { Frontier } \\
\text { Analysis }\end{array}$ & Value-added Approach \\
\hline Tsionas et al. (2003) & Greece & DEA & $\begin{array}{l}\text { Intermediation } \\
\text { Approach }\end{array}$ \\
\hline $\begin{array}{l}\text { Guzman and Reverte } \\
\text { (2008) }\end{array}$ & Spain & DEA & $\begin{array}{l}\text { Intermediation } \\
\text { Approach }\end{array}$ \\
\hline $\begin{array}{l}\text { Tortosa-Ausina et al. } \\
\text { (2008) }\end{array}$ & Spain & DEA & $\begin{array}{l}\text { Intermediation } \\
\text { Approach }\end{array}$ \\
\hline $\begin{array}{l}\text { Işik and Hassan } \\
(2003)\end{array}$ & Turkey & DEA & $\begin{array}{l}\text { Intermediation } \\
\text { Approach }\end{array}$ \\
\hline
\end{tabular}

Fiordelisi and Molyneux (2010) examined the impact of TFP and its components on the variations in bank shareholders value in European banking (France, Germany, Italy, UK) over the period 1995-2002, using DEA and intermediation approach. They found that TFP improvements cause a higher bank shareholder value. Among the components 
of TFP, technological changes and/or technical efficiency changes lead banks to create a shareholder value. But, technological changes have the largest impact. More recently, Koutsomanoli-Filippaki et al. (2009) examined the banking productivity change in 10 CEE countries over the period 1998-2003. The approach to output definition used in this study is the intermediation approach. They found that most countries show productivity improvement after 2000 as a result of fulfillment of banking reforms and close-by EU accession. However, productivity growth diverged across the banking systems. Furthermore, technological change is the source of productivity change and foreign banks show the highest productivity compared with domestic private and state-owned banks.

To summarize, this comprehensive study attempts to contribute to the cross-country banking comparison literature by linking and comparing across the EU banking systems of the old and new members and the candidate countries; and also to find out how European integration determines domestic banking productivity.

\section{Methodology}

The convergence literature, which is well established, generally tests for the convergence of real income per capita among countries. Barro and Sala-i-Martin (1991) proposed two concepts of convergence: $\beta$ (beta)-convergence and $\sigma$ (sigma)-convergence. $\beta$-convergence implies that if countries differ with regard to the initial level of any variable, and if one group of countries (low initial levels) grows faster than the other (high initial levels) in the long run, they will all converge to the same steady state. Hence, $\beta$-convergence exists if the growth rate is negatively correlated with the initial level. In this study, we test for the convergence of total factor productivity. The tests for convergence of total factor productivity provide some insight as to the spread, adoption and convergence of technical advances. In our case, $\beta$-convergence implies that countries with a lower level of productivity have faster growth rates than countries with a higher level of productivity.

The regression equation for the test of $\beta$-convergence has the following form:

$$
\ln \left(\mathrm{TFP}_{i t}\right)=\alpha+(1+\beta) \ln \left(\mathrm{TFP}_{i, t-1}\right)+\varepsilon_{i t},
$$

where $0<\beta<1$ and $\varepsilon_{i t}$ has mean zero, finite variance and is independent over $t$ and $i$. TFP $_{i t}$ denotes the mean TFP growth of the banks of country $i$ in year $t^{4}$. Manipulating Eq. (1) yields:

$$
\ln \left(\frac{\mathrm{TFP}_{i t}}{\mathrm{TFP}_{i, t-1}}\right)=\alpha+\beta \ln \left(\mathrm{TFP}_{i, t-1}\right)+\varepsilon_{i t} .
$$

Hence, $\beta$-convergence occurs when the $\beta$ coefficient is negative, and the magnitude of $\beta$ denotes the speed of convergence.

It is also common in convergence studies to measure the cross-sectional dispersion of the level of any variable over time. This is known as $\sigma$ (sigma)-convergence. This type

\footnotetext{
${ }^{4}$ The technical derivation of the Malmquist total factor productivity index is provided in Appendix.
} 
of convergence might be presented in terms of the standard deviation of levels across countries. If the standard deviation declines over time there is evidence of $\sigma$-convergence. $\beta$-convergence is a necessary but not sufficient condition for $\sigma$-convergence since a shock can temporarily increase the dispersion in variable across countries even when countries are converging to a steady state (see Quah, 1996). In this paper, we also examine $\sigma$-convergence to check whether the dispersion of productivity levels decreases over time. The test of $\sigma$-convergence is performed using the following equation:

$$
\Delta D=\alpha+\beta D_{i, t-1}+\varepsilon_{i t},
$$

where $D=\left(\ln T F P_{i t}\right)-\left(\overline{\ln \mathrm{TFP}_{i t}}\right)$ and $\Delta D=D_{i t}-D_{i, t-1}$. Here, $\ln \left(\mathrm{TFP}_{i t}\right)$ denotes the natural logarithm of the mean productivity level of banks of country $i$ in year $t$ and $\left(\overline{\ln \mathrm{TFP}_{i t}}\right)$ denotes the mean of $\ln \left(\mathrm{TFP}_{i t}\right)$ for each period. There is $\sigma$-convergence if the $\beta$ coefficient of the initial level is negative.

\section{Data and empirical results}

\subsection{Data}

Bank level data for all countries in the sample were obtained from the Bankscope database. The data were reviewed for reporting errors, inconsistencies, missing values and extreme values. The sample includes commercial, cooperative, and savings banks. We use these three banking categories as they comprise the largest portion of depository institutions in the EU banking markets. Choosing the appropriate definition of bank output is a relevant issue in the estimation of banking performance. Four approaches (i.e., production, intermediation, value added and user-cost) have suggested by researchers. Although no approach can be considered superior to the others, the intermediation approach, which is commonly used in the related literature, is adopted in the present paper. Hence, two outputs are defined: total customer loans and other earning assets (investment securities). Three inputs are used: total purchased funds (total interest expenses), number of employees (personnel expenses), and fixed assets (other operating expenses). The Bankscope database does not include number of employees for most of the banks. Hence, in this study we use total interest expenses, personnel expenses, and other operating expenses as inputs. We dropped countries that have a total number of banks equal to or less than twelve from the analysis ${ }^{5}$. One old EU member, Greece, and four new EU members, Slovakia, Slovenia, Malta and Estonia, countries were omitted from the sample due to many missing values for the variables used in the analysis. Table 2 reports the number of banks and summary statistics of variables used in the study for each sampled country.

\footnotetext{
${ }^{5}$ Coelli et al. (1999) state that using a large number of outputs and inputs with a small sample size would result in many firms appearing on the efficient frontier. This statement was confirmed in our analysis as well. Using intermediation approach, we defined two outputs (total loans, other earning assets) and three inputs. The Data Envelopment Analysis (DEA) results indicate that most sampled banks appeared to be efficient (i.e. efficiency score is equal to 1) when we use sample size smaller than twelve banks. Hence, to avoid this problem, we dropped countries that have small sample size.
} 


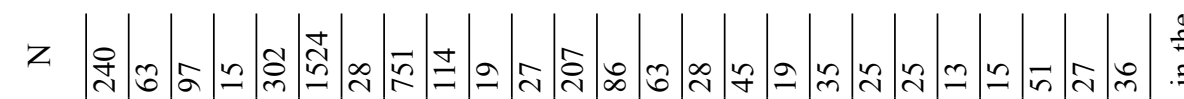
=

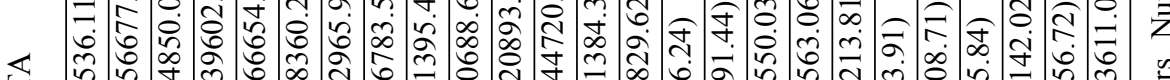

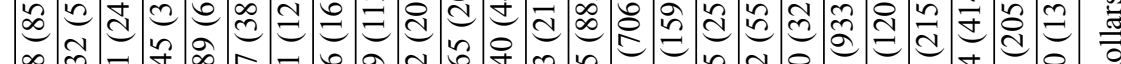

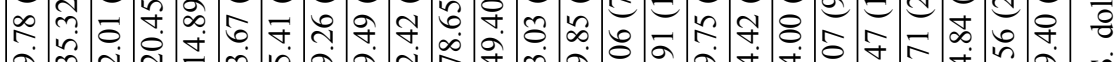

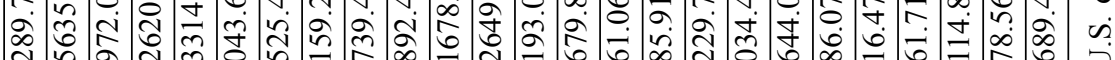
స̂.

预 岂

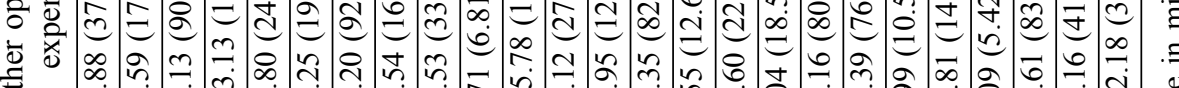

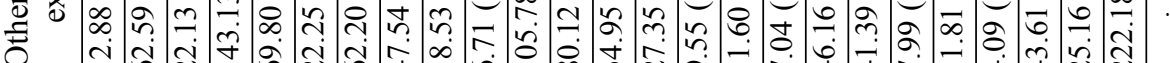

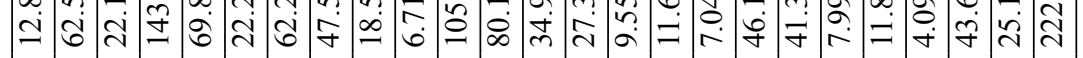

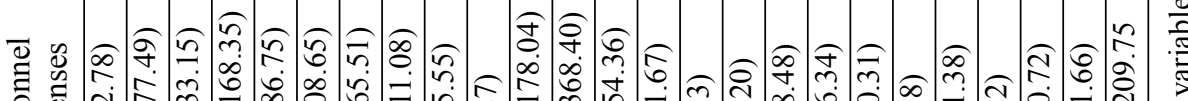

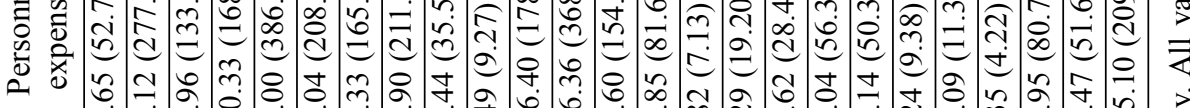

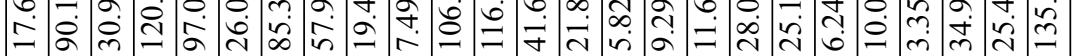

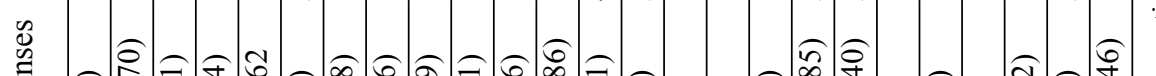

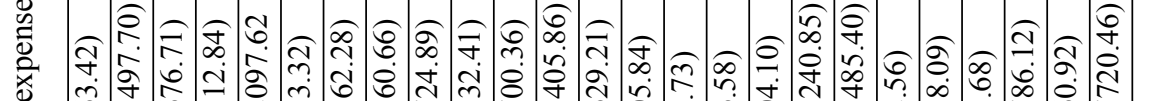
范

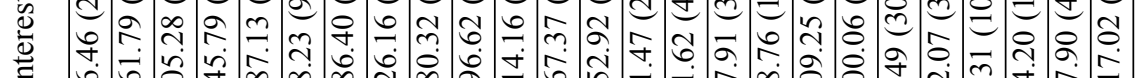

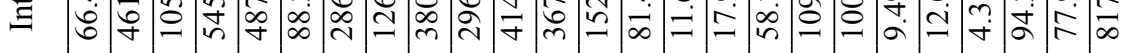

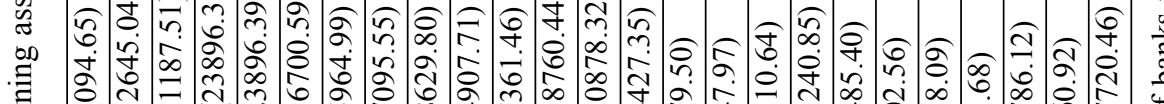

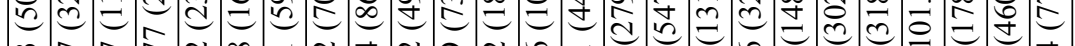

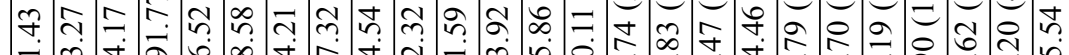
ப்

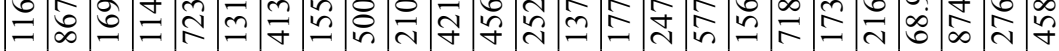
-

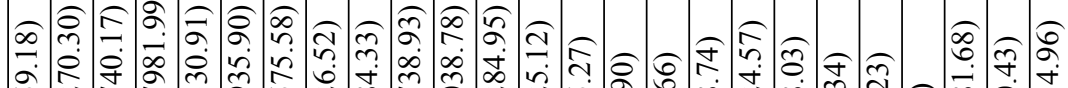

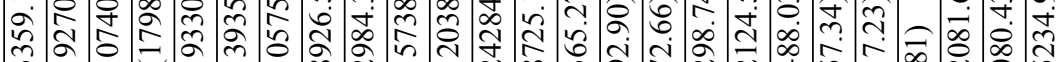

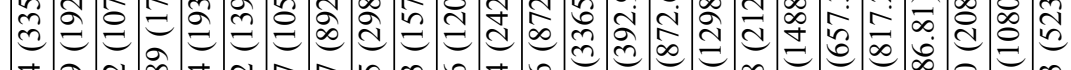

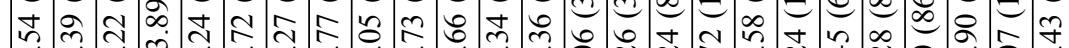

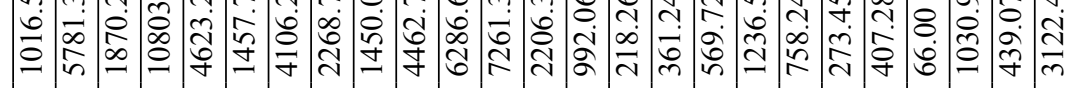

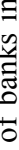




\subsection{Empirical results}

The Malmquist total factor productivity (TFP) change for banking firms in the old and new EU member and candidate countries for the period 1995-2006 are reported in Tables 3 and 4, respectively. An index greater than one indicates a positive TFP growth while an index lower than one indicates a decrease of TFP over the sample period. Productivity change is then decomposed into technical efficiency change (TE) and technical change (TC). An improvement in TE is considered as the "catching-up", whereas an improvement in TC is a shift in the best-practice frontier. The TE is further decomposed into the scale efficiency change (SE) and pure efficiency change (PE) components. The main advantage of the decomposition is that it provides information on the sources of the overall productivity change in the banking sectors of the sampled countries ${ }^{6}$.

The entries in each column of Tables 3 and 4 are annual geometric means of results of individual banks and the last column in the table reports geometric means of the annual geometric means of each country. Moreover, the last five rows in each Table report the geometric means of the results considering all banks together (the EU-22 and three candidate countries).

The results in Table 3 indicate that all banking sectors in the old EU member countries seem to have experienced a significant productivity growth over the sample period, particularly for Spanish $(15.6 \%)$ and Italian banks $(13.5 \%)$. These results are in line of the findings of Casu et al. (2004). Productivity growth has been relatively modest for Swedish (2.5\%), Irish (3.1\%), British (3.4\%) and Dutch banks (3.6\%). As for the other sampled countries, the productivity growth has been moderate, for instance $4.6 \%$ for German, $6.8 \%$ for Austrian, $8 \%$ for French, and $8.8 \%$ for Portuguese banks. From an analysis of the decomposition of the Malmquist TFP, productivity growth in old EU member countries' banking systems seem to have been brought about mainly by a positive technical change (for instance $15.8 \%$ for Italy, $12.2 \%$ for Spanish, and 9.6\% for Danish banks). These results are similar to Mukherjee et al.'s (2001) and Casu et al.'s (2004) findings on US banks and EU banks, respectively, where technical change is found to derive productivity growth. In addition, all sampled banking sectors with the exception of Spanish and Swedish banks seem to have been able to exploit also some catching up effect.

Austrian banking sector shows a significant improvement in the TFP index with an overall increase in productivity of $6.8 \%$. This productivity growth seems to have been brought about by improvement in technical efficiency $(4.7 \%)$ rather than a positive technical change. The productivity growth in the British banking sector also seems to have been brought about by improvement in technical efficiency (16.5\%). Moreover, the size of technical change is greater than the size of technical efficiency change in all countries with the exception banks in Austria, Luxemburg, the Netherlands and the UK. As for the scale efficiency (SE) change, all sampled banking sectors with the exception of Sweden, display positive scale efficiency change.

\footnotetext{
${ }^{6}$ The indices in the table are calculated relative to the previous year.
} 
Overall, despite the evidence of TFP growth in all sampled countries, it fluctuates over the sample period. Although there does not seem to a clear trend banking sector become less productive in recent years. The analysis of the decomposition of the TFP index into its technical change (TC) and technical efficiency change (TE) components shows different trends. Whereas there seem to have been considerable technological changes over sample period (although with a decreasing trend in all countries in recent years as in the TFP case), no clear trend seems to exists for technical efficiency change, which stays above one but stays relatively steady in most sampled countries.

The last few rows in Table 3 report the geometric means of the results considering all banking firms in the old member countries together. As revealed by the last row in the table, productivity growth has occurred for the overall 1995-2006 period (except for year 2000 and 2006), considering all firms and countries together. This productivity growth has involved simultaneously technical change $(1.6 \%)$ and technical efficiency change $(7.0 \%)$.

The results of Malmquist total factor productivity (TFP) change for banking firms in the new EU member and candidate countries are reported in Table 4. The results indicate that all banking sectors in the new EU member and candidate countries also seem to have experienced a significant productivity growth over the sample period, ranging from $6.8 \%$ for FRY Macedonia to $19.5 \%$ for Romania. Productivity growth has been relatively higher for Bulgarian (14\%), Lithuanian (14.3\%), Latvian (10.5\%), Polish (9.7\%) and Hungarian (9.5\%) banks. As for the other sampled countries, the productivity growth has been moderate, for instance, $7.4 \%$ for Cyprus, $7.6 \%$ for Croatia, $7.7 \%$ for Turkey and $9.2 \%$ for the Czech Republic. The results indicate that overall productivity growth for the new member and candidate countries is higher than that of the old member countries. These results may reflect the impacts of implementing a number of measures required by EU directives, which aim at the liberalization and modernization of the banking systems. Moreover, these efforts to prepare the banking systems for the new legal and economic environment have also affected the performance and productivity in these countries. The impact of regulatory changes, foreign entry, and consolidation is particularly clear on the productivity growth after 1999.

Focusing on the components of the TFP indices, the results indicate that the improvement in productivity seems to have been caused by a positive technical change in more than half of the sampled countries. However, there has been also a significant catching up effect on the improvement in productivity in all sampled countries. There has been technical regress only in Cyprus over the sample period. The technical efficiency change is found to derive productivity in Cyprus (25.8\%). Overall, our results suggest both an improvement of the boundary of production over time (progress in technology) and movement of the non-best practice banks towards the frontier (improvement in technical efficiency). The results also indicate that on average marginal improvement in the technical efficiency levels is mostly due to an increase in pure technical efficiency over the sample period in most sampled countries. However, all sampled banking sectors with the exception of the Czech Republic display positive scale efficiency change, indicating that, on average, banks in the sampled countries are operating at a more efficient scale. 


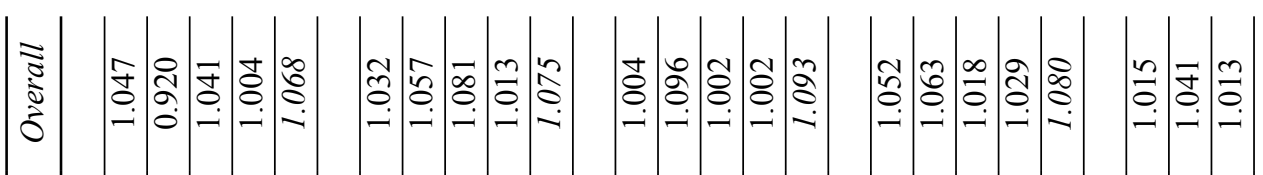

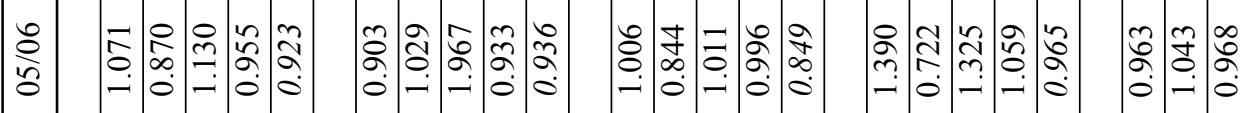

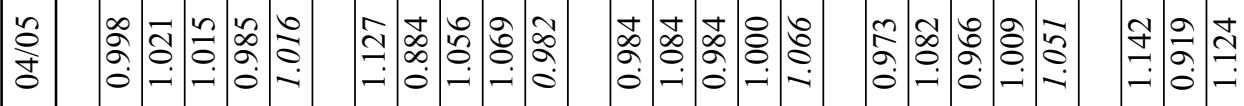

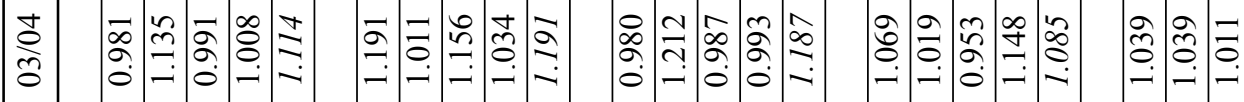

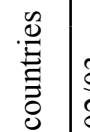

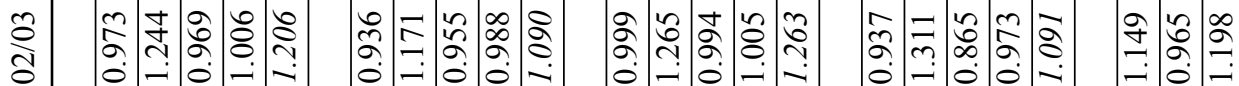

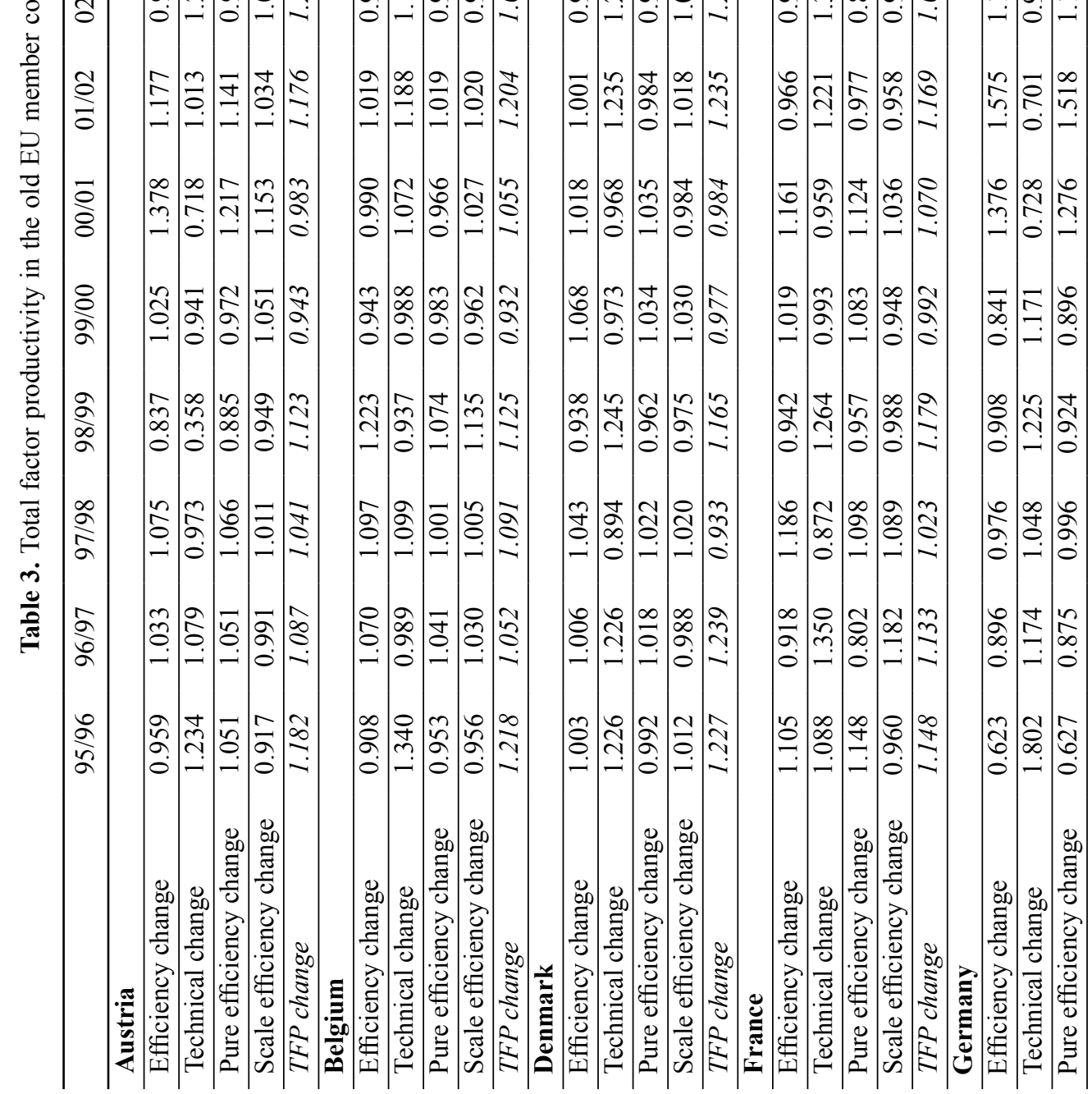


$m$
$\frac{0}{0}$
0
0
0
0
0
0
0
0

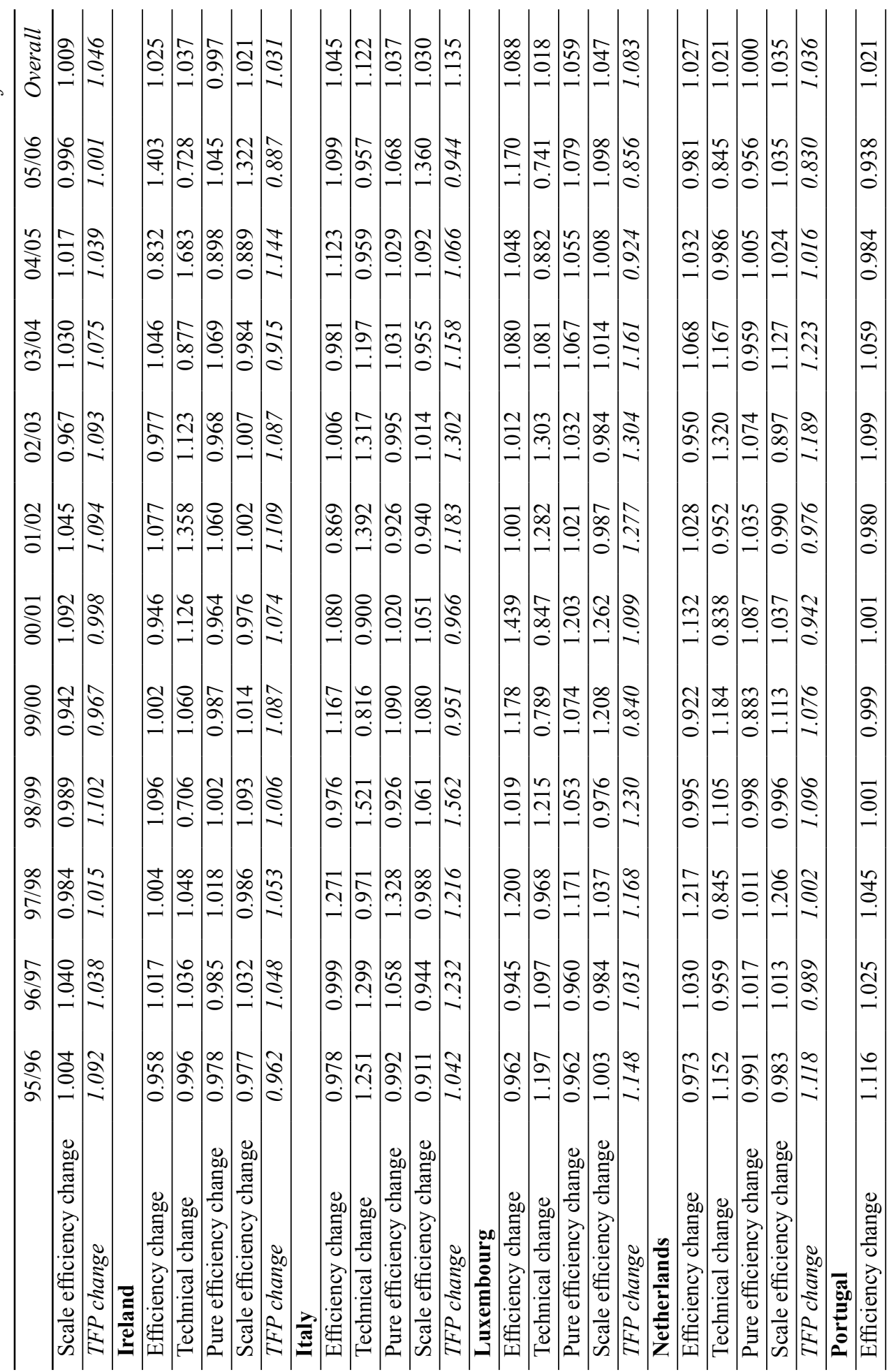


$\frac{0}{0}$
$\frac{0}{0}$
$\frac{1}{0}$
$\frac{1}{0}$

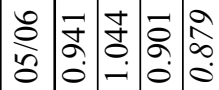

is

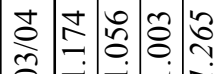

ल $=-\dot{-}$

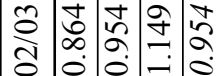

일

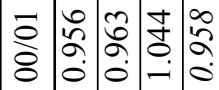

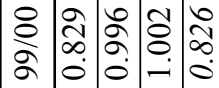

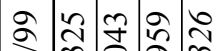

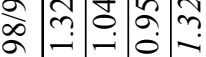

$\stackrel{2}{2} \approx \widetilde{2}$

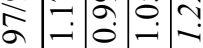

ลิ) ๙े

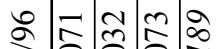
ă

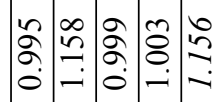

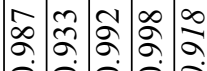

$\begin{array}{lllll}0 & 0 & 0 & 0 & 0 \\ 0 & 0 & 0\end{array}$

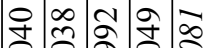

-

ㄱำ

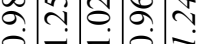

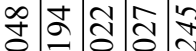

$\dot{-i}-\dot{i}-$

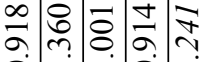

$\dot{0}-\dot{0} \dot{0}-$

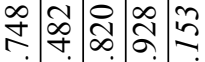

- $-\dot{0} 0$.

ㅇํ용

$\dot{0}-\dot{0}-\dot{0}$

๗ి

तิ

$\infty$ $\exists=\because$ ت $=$

$28 \approx \hat{x}$

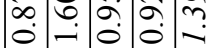

응 영

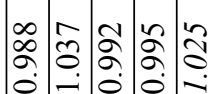

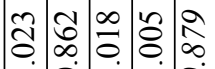

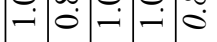

잉 ปิ

$-\dot{-i} \dot{0}-$

\&̊

-i $-\dot{i}-i$

우롷ำ

ڤે

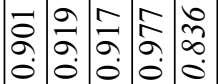

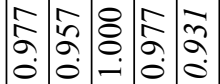

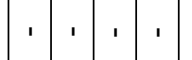

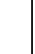

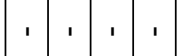

二

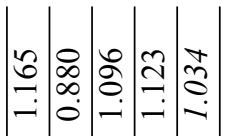

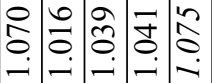

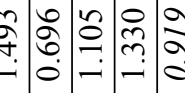

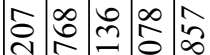

- $\dot{0}=$

ஸ் তิ $\frac{\infty}{0} \approx$

$-\dot{-}-\dot{-}-$

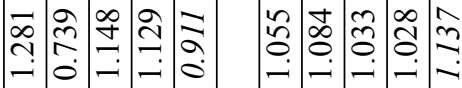

守寻寻

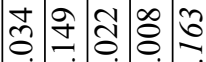

$-\dot{0}-\dot{-}-\dot{ }$

‡

$-0 \sim-1$

文

ริ

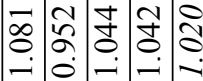

กิ

กิ

- $0-\dot{-}-\dot{0}$

ㅇํำ

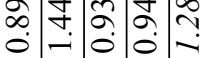

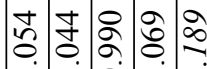

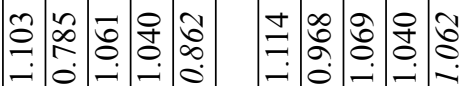

ᄃ

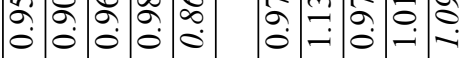

공

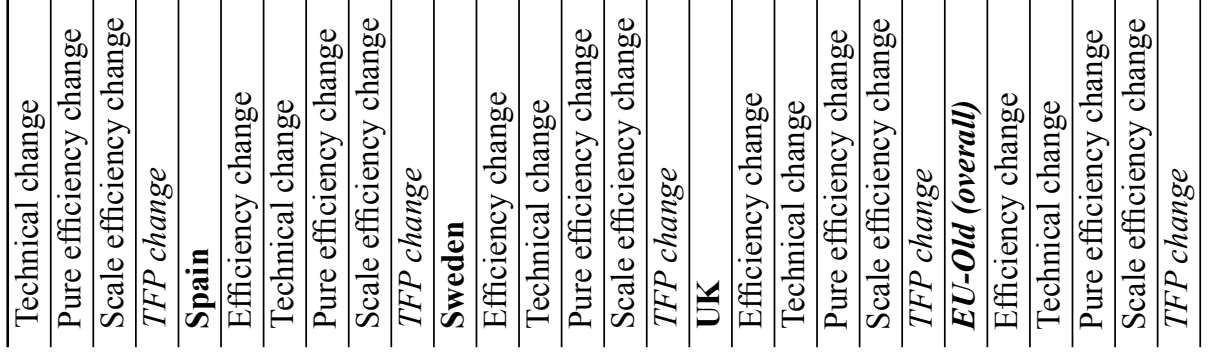


The TFP growth in the new EU and candidate countries fluctuates over the sample period. The TFP indices for all countries are above one with a few exceptions of 1997, 1998 and 1999. The decline in productivity in some new member countries during the initial years of our sample may be due to the fact that banking reforms had not yet been completed in these countries. This result may also reflect the different timing and the implementation of the banking reforms among the new member and candidate countries. Although there does not seem a clear trend, banking sectors became more productive over the period 1999-2004. However, banking sectors have become less productive in recent years. The analysis of the decomposition of the TFP index into its technical change (TC) and technical efficiency change (TE) components shows different trends. The results indicate that the TC and TE indices fluctuate more than the TFP indices in most of the sampled banking sectors. However, these indices are above one over the sample period.

The last few rows in Table 4 reports geometric means of results considering all banking firms in the new member and candidate countries together. As revealed by the last row in the table, productivity growth has occurred for the overall period 1995-2006. The results suggest that productivity has been growing at a higher rate $(10.6 \%)$. As in the case of old EU member countries, productivity growth seems to have been brought about by technical efficiency change (6.4\%) and technical change (4.6\%). These results do not support the findings of Koutsomanoli-Filippaki et al. (2009) who investigated the efficiency and productivity growth of the banking industry in ten CEE countries over the period 1998-2003 using a stochastic directional technology function. Their results indicate that during the initial years of their sample (1998-2000), there was an overall decline in productivity. This picture, however, is reversed during the latter years of their sample (2002-2003). Our findings also show a decrease in the TFP change between 1995 and 1999, then an increase afterwards but the TFP change is always above one during the sample period. These differences in the findings of the two studies could be attributed to the different methodologies used in these studies. Moreover, our results also suggest that the banking sectors in the new EU member and candidate countries were more productive than those of in the old EU member countries, on average.

During the sample period, interest shown to the banking sectors in the new member and candidate countries from foreign investors significantly increased. Banking sectors in developed countries have reached saturation and as a result foreign investors are now seeking for new and unexploited opportunities. Foreign investors, particularly from the old EU member countries, have started to enter the banking sectors in the Central and Eastern European countries through merger and acquisitions since the second half of the 1990s. The share of foreign banks in these sectors has increased significantly in recent years. The main contribution of foreign banks is that they bring technology and know-how to the banking systems. Overall, these findings suggest that the entrance of foreign investors, regulatory harmonization with the EU, the consolidation process and investments in new technology in the new member and candidate countries have led the banking firms to increase their technical efficiency and productivity, and to operate at a more efficient scale. 


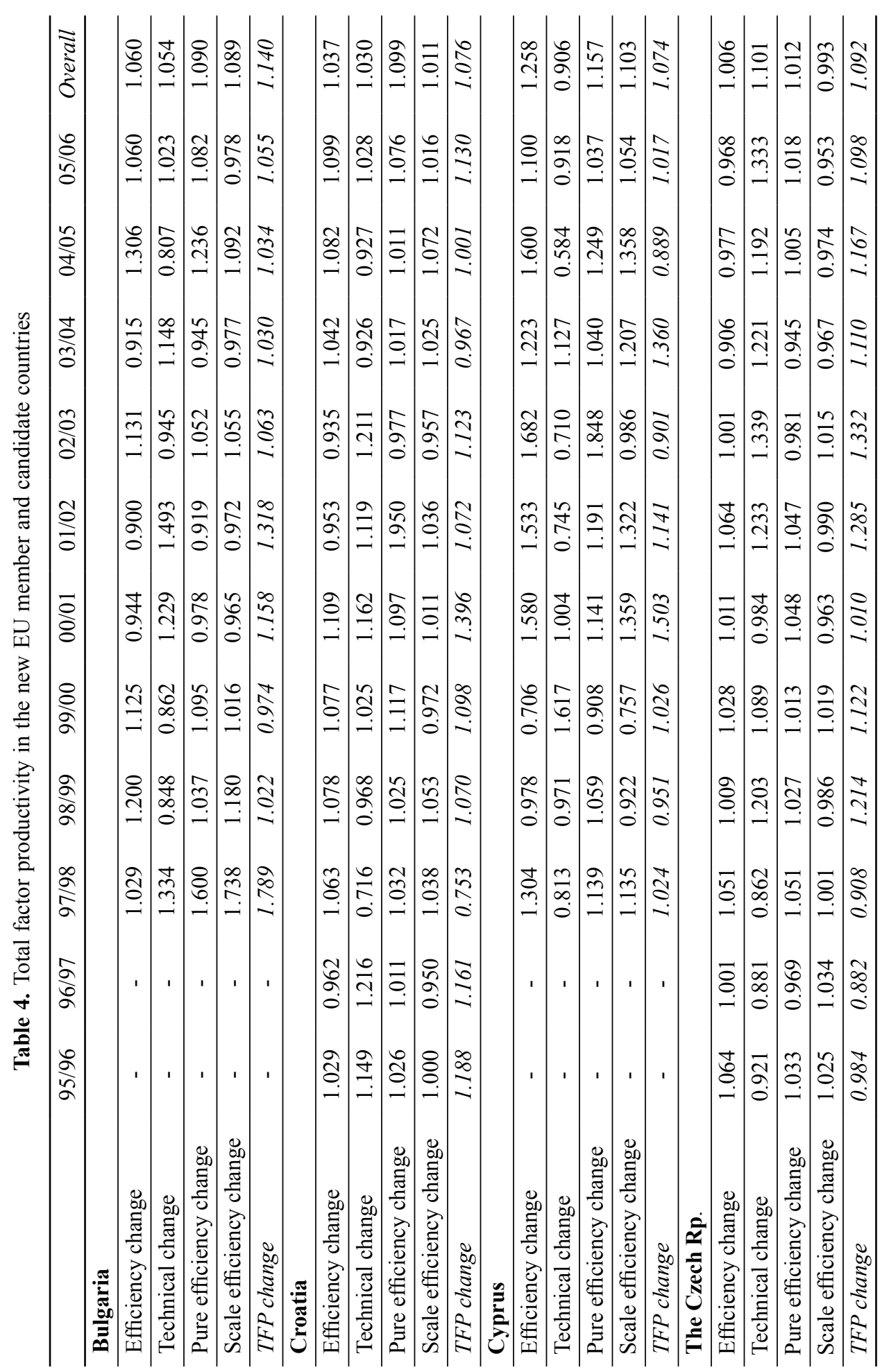




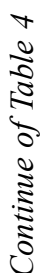

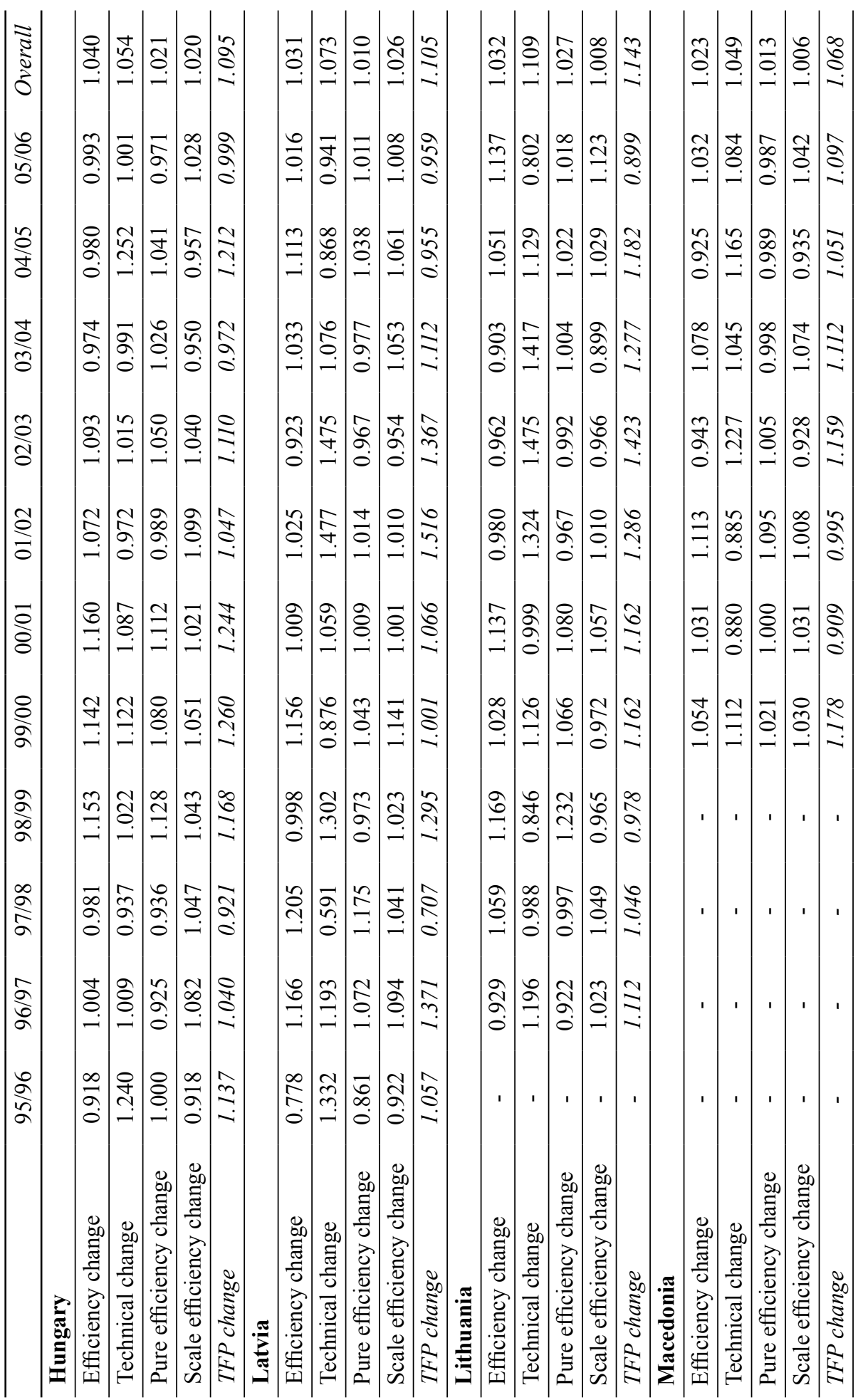




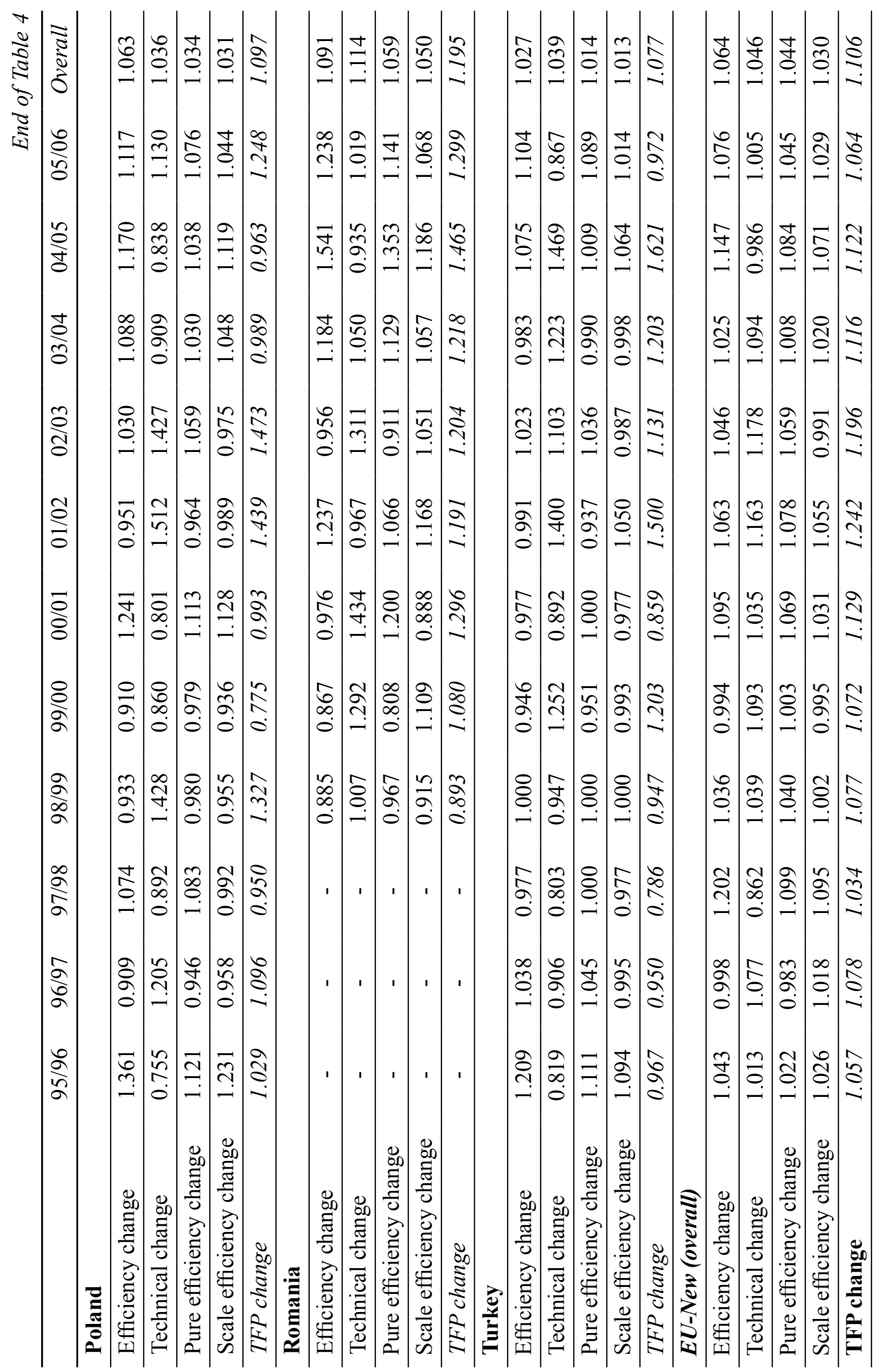




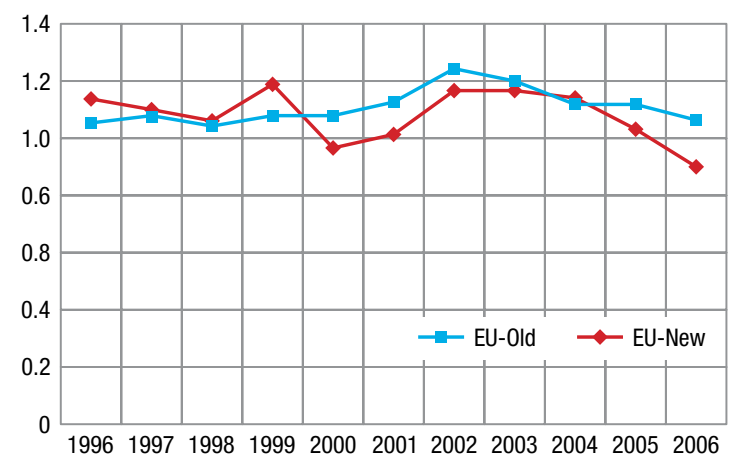

Fig. 1. Evolution of TFP change in the old and new EU member countries

The evolution of mean TFP changes is also examined. Figure 1 presents the evolution of mean TFP change of two groups of countries. The mean TFP change for both groups fluctuates along the eleven years of our sample. Although there does not seem to be a clear trend, banking sectors in new EU member countries have become more productive between 1998-2002. The mean TFP change is above one in recent years but it has downward trend. As for the old members, mean TFP changes fluctuate within a narrow range. However, these banking systems also seem to have become more productive particularly, between 2000 and 2004 but have shown a downward trend in recent years. As seen in Figure 1, the mean TFP change levels for the new member and candidate countries are above those of old member countries between 1999 and 2006 with the exception of year 2004. Moreover, it seems that mean TFP change levels in two groups are correlated.

Following the observed evolution of total factor productivity, convergence tests are of great interest for checking whether there is convergence in banking productivity across the old and new EU member and candidate counties. The results of the regression for $\beta$-convergence and $\sigma$-convergence in total factor productivity are reported in Table 5. Both tests are employed for the full sample of countries over the sample period. As seen in the table, the coefficients of $\ln \left(\mathrm{TFP}_{i, t-1}\right)$ and $D_{i t-1}$ are negative and statistically significant at the $1 \%$ level. Hence, these results indicate evidence of both $\beta$-convergence and $\sigma$-convergence in banking productivity among twenty two EU member and three candidate countries.

Hence, the main finding of this paper is the convergence in banking productivity across EU member and candidate countries, and is of importance ${ }^{7}$. This result suggests that most productive banking industry at the beginning of the sample period have shown a lower growth rate in TFP than the least productive banking industry. Moreover, the results also suggest that the dispersion of the mean TFP growth among the sampled banking industries declined over the sample period.

\footnotetext{
${ }^{7}$ We also examined convergence in technical efficiency, scale efficiency, technical change and pure efficiency change. The results indicate evidence of both beta-convergence and sigma-convergence in technical efficiency, scale efficiency, technical change and pure efficiency change among the EU member and candidate countries.
} 
Table 5. Regression results for productivity convergence: the older and newer EU member and candidate countries

\begin{tabular}{lcc}
\hline & Coefficient & Standard Error \\
\hline$\beta$-convergence & & \\
\hline Constant & $0.054^{*}$ & 0.012 \\
\hline $\ln \left(\mathrm{TFP}_{i, t-1}\right)$ & $-0.918^{*}$ & 0.070 \\
\hline $\bar{R}^{2}$ & 0.43 & \\
\hline$\sigma$-convergence & & 0.010 \\
\hline Constant & -0.005 & 0.077 \\
\hline$D_{i t-1}$ & $-0.957^{*}$ & \\
\hline $\bar{R}^{2}$ & 0.46 & $R^{2}$ \\
\hline
\end{tabular}

Notes: Figures in parentheses are p-values. * denotes significance level at $1 \% . \bar{R}^{2}$ denotes adjusted R-squared.

\section{Conclusions}

This paper has investigated productivity growth in the banking sectors of twenty-two EU member and three candidate countries over the period 1995-2006. Fourteen countries were considered as the old EU member countries. The main objective of this study was to examine whether the banking markets have been integrated, by analyzing the convergence in productivity growth for the sampled countries. Our findings indicate that all banking sectors in the old EU member countries seem to have experienced a significant productivity growth over the sample period. The productivity growth levels range from $3.1 \%$ in Ireland to $15.6 \%$ in Spain. As for the new member and candidate countries, the results indicate that all banking sectors also seem to have experienced a significant productivity growth, ranging from $6.8 \%$ in FRY Macedonia to $19.5 \%$ in Romania. From an analysis of the decomposition of the Malmquist TFP, productivity growth in the old EU member countries' banking systems seem to have been brought about mainly by a positive technical change. The results also indicate that the improvement in productivity in new member countries seems to have been brought about by technical efficiency change (the catching up effect) and technical change. The geometric means considering all banking firms in the new member and candidate countries together reveal that productivity growth has occurred over the sample period. The results also suggest that banking sectors in new EU member and candidate countries were more productive than those of in the old EU member countries. Overall, the results indicate that financial integration has had a positive impact on productivity and efficiency of banks operating, particularly in the banking sectors of the new EU member and candidate countries.

The results of convergence analysis suggest that there is a catching-up process in banking productivity and efficiency across the old and the new EU member and candidate countries. Hence, those with the least productive banking sectors initially had the highest rates of improvement in productivity over the sample period. The test results of con- 
vergence in productivity show the evidence of both $\beta$-convergence and $\sigma$-convergence in productivity growth (and also in technical efficiency change, technical change, pure technical change and scale efficiency change across the sampled countries), providing some evidence in favor of the process of banking markets integration in the EU.

Overall, our results suggest that the structural changes undergone in the old and new members of the EU due to the financial integration process have increased competition, efficiency and productivity in most EU countries. Some policy implications can be drawn from the findings of this study. The evidence indicates that promoting merger and acquisition activities in the banking system (and hence supporting market driven consolidation of smaller banks) and enhancing the presence of foreign banks could increase competition, productivity and efficiency in these banking systems. Hence, the differences in the productivity and efficiency levels across the EU member and candidate countries could disappear in near future.

\section{Acknowledgements}

This study is fully supported by the Turkish Scientific and Technological Research Council under the project no. SOBAG-107K190.

\section{References}

Ali, A. I.; Gstach, D. 2000. The Impact of deregulation during 1990-1997 on banking in Austria, Empirica 27(3): 265-281. http://dx.doi.org/10.1023/A:1007164501521

Akin, A.; Bayyurt, N.; Zaim, S. 2013. Managerial and technical inefficiencies of foreign and domestic banks in Turkey during the 2008 global crisis, Emerging Markets Finance and Trade 49(3): 48-63. http://dx.doi.org/10.2753/REE1540-496X490304

Barro, R.; Sala-I-Martin, X. 1991. Convergence across states and regions. Brookings Papers on Economic Activity 1991(1): 107-182. http://dx.doi.org/10.2307/2534639

Bonin, P. J.; Hasan, I.; Wachtel, P. 2003. Bank performance, efficiency and ownership in transition countries, in 9th Dubrovnik Economic Conference, 26-28 June, 2003, Dubrovnik, Croatia.

Canhoto, A. M.; Dermine, J. 2003. A note on banking efficiency in Portugal, New vs. Old banks, Journal of Banking and Finance 27(11): 2087-2098.

http://dx.doi.org/10.1016/S0378-4266(02)00316-3

Casu, B.; Molyneux, P. 2003. A comparative study of efficiency in European banking, Applied Economics 35(17): 1865-1876. http://dx.doi.org/10.1080/0003684032000158109

Casu, B.; Girardone, C.; Molyneux, P. 2004. Productivity change in European banking: a comparison of parametric and non-parametric approaches, Journal of Banking and Finance 28(10): 2521-2540. http://dx.doi.org/10.1016/j.jbankfin.2003.10.014

Casu, B.; Girardone, C. 2005. An analysis of the relevance of off-balance sheet items in explaining productivity change in European banking, Applied Financial Economics 15(15): 1053-1061. http://dx.doi.org/10.1080/09603100500120688

Chaffai, M. E.; Dietsch, M.; Lozano-Vivas, A. 2001. Technological and environmental differences in the European banking industries, Journal of Financial Services Research 19(1/2): 147-162. http://dx.doi.org/10.1023/A:1011107404524

Coelli, T.; Rao, S. P.; Battese, G. 1999. An introduction to efficiency and productivity analysis. USA: Kluwer Academic Publishers. 
Fare, R.; Grosskopt, S.; Lindgren, B.; Roos, P. 1994. Productivity developments in Swedish hospitals: a Malmquist output index approach, in A. Charnes, W. Cooper, A. Y. Lewin, L. M. Seiford (Eds.). Data Envelopment analysis: theory methodology and applications. Boston: Kluwer Academic Publishers, 253-272.

http://dx.doi.org/10.1007/978-94-011-0637-5_13

Farrell, M. J. 1957. The measurement of productive efficiency, Journal of the Royal Statistical Society 120(3): 253-81. http://dx.doi.org/10.2307/2343100

Fries, S.; Taci, A. 2005. Cost efficiency of banks in transition: evidence from 289 banks in 15 post-communist countries, Journal of Banking and Finance 29(1): 55-81.

http://dx.doi.org/10.1016/j.jbankfin.2004.06.016

Fiordelisi, F.; Molyneux, P. 2010. Total factor productivity and shareholder returns in Banking, Omega 38(5): 241-253. http://dx.doi.org/10.1016/j.omega.2008.07.009

Goddard, J.; Liu, H.; Molyneux, P.; Wilson, J. 2013. Do bank profits converge?, European Financial Management 19(2): 345-365. http://dx.doi.org/10.1111/j.1468-036X.2012.00578.x

Grifell-Tatje, E.; Lovell, C. A. K. 1997. The sources of productivity change in Spanish banking, European Journal of Operational Research 98(2): 364-380.

http://dx.doi.org/10.1016/S0377-2217(96)00353-0

Grigoran, D. A.; Manole, V. 2006. Determinants of commercial bank performance in transition: an application of data envelope analysis, Comparative Economic Studies 48(3): 497-522.

http://dx.doi.org/10.1057/palgrave.ces.8100129

Guzman, I.; Reverte, C. 2008. Productivity and efficiency change and shareholder value: evidence from the Spanish banking sector, Applied Economics 40(15): 2033-2040.

http://dx.doi.org/10.1080/00036840600949413

Hasan, I.; Marton, K. 2003. Development and efficiency of the banking sector in a transitional economy: Hungarian experience, Journal of Banking and Finance 27(12): 2249-2271.

http://dx.doi.org/10.1016/S0378-4266(02)00328-X

Işık, I.; Hassan, M. K. 2003. Financial deregulation and total factor productivity change: an empirical study of Turkish commercial banks, Journal of Banking and Finance 27(8): 1455-1485. http://dx.doi.org/10.1016/S0378-4266(02)00288-1

Kasman, A. 2005. Efficiency and scale economies in transition economies: evidence from Poland and the Czech Republic, Emerging Markets Finance and Trade 41(6): 60-81.

Kasman, A.; Yildirim, C. 2006. Cost and profit efficiencies in transition banking: the case of new EU members, Applied Economics 38(9): 1079-1090. http://dx.doi.org/10.1080/00036840600639022

Koutsomanoli-Filippaki, A.; Margaritis, D.; Staikouras, C. 2009. Efficiency and productivity growth in the banking industry of Central and Eastern Europe, Journal of Banking and Finance 33(3): 557-567. http://dx.doi.org/10.1016/j.jbankfin.2008.09.009

Kumbhakar, S. C.; Lozano-Vivas, A; Knox Lovell, C. A.; Hasan, I. 2001. The effects of deregulation on the performance of financial institutions: the case of Spanish savings banks, Journal of Money, Credit and Banking 33(1): 101-120. http://dx.doi.org/10.2307/2673874

Lozano-Vivas, A.; Pastor, J. T. 2006. Banking and economic activity performance: an empirical study at the country level, The Manchester School 74(4): 469-482.

http://dx.doi.org/10.1111/j.1467-9957.2006.00504.x

Mamatzakis, E.; Staikouras, C.; Koutsomanoli-Filippaki, A. 2008. Bank efficiency in the new European Union member states: is there convergence?, International Review of Financial Analysis 17(5): 1156-1172. http://dx.doi.org/10.1016/j.irfa.2007.11.001

Matousek, R. 2008. Efficiency and scale economies in banking in new EU countries, International Journal of Monetary Economics and Finance 1(3): 235-249.

http://dx.doi.org/10.1504/IJMEF.2008.020633 
Mörttinen, L. 2002. Banking sector output and labour productivity in six European countries, Bank of Finland Research Discussion Papers No:12/2002.

Mukherjee, K.; Ray, S. C.; Millar, S. M. 2001. Productivity growth in large US banks: the initial post deregulation experience, Journal of Banking and Finance 25(5): 913-939.

http://dx.doi.org/10.1016/S0378-4266(00)00103-5

Pastor, J. M.; Perez, F.; Quesada, J. 1997. Efficiency analysis in banking firms: an international comparison, European Journal of Operational Research 98(2): 395-407.

http://dx.doi.org/10.1016/S0377-2217(96)00355-4

Quah, D. 1996. Empirics of economic growth and convergence, European Economic Review 40(6): 1353-1376. http://dx.doi.org/10.1016/0014-2921(95)00051-8

Rebelo, J.; Mendes, V. 2000. Malmquist indices of productivity change in Portuguese banking: the deregulation period, International Advances in Economic Research 6(3): 531-543.

http://dx.doi.org/10.1007/BF02294970

Shepherd, R. W. 1970. Theory of Cost and Production Function. Princeton, NJ: Princeton University Press.

Stavarek, D. 2006. Banking efficiency in the context of European integration, Eastern European Economics 44(4): 5-31. http://dx.doi.org/10.2753/EEE0012-8775440401

Tortosa-Ausina, E.; Grifell-Tatje, E.; Armero, C.; Conesa, D. 2008. Sensitivity analysis of efficiency and Malmquist productivity indices: an application to Spanish savings banks, European Journal of Operational Research 184(3): 1062-1084. http://dx.doi.org/10.1016/j.ejor.2006.11.035 Tsionas, E. G.; Lolos, S. E. G.; Christopoulos, D. K. 2003. The performance of the Greek banking system in view of the EMU: results from a non-parametric approach, Economic Modelling 20(3): 571-592. http://dx.doi.org/10.1016/S0264-9993(01)00101-8

Weill, L. 2009. Convergence in banking efficiency across European countries, International Financial Markets, Institutions, and Money 19(5): 818-833.

http://dx.doi.org/10.1016/j.intfin.2009.05.002

Yildirim, H. S.; Philippatos, G. C. 2006. Efficiency of banks: recent evidence from the transition economies of Europe, 1993-2000, The European Journal of Finance 13(2): 123-43.

http://dx.doi.org/10.1080/13518470600763687

\section{APPENDIX 1}

\section{Malmquist total factor productivity index}

The Malmquist TFP index is the most commonly used measure of productivity change in empirical studies since it enables us to decompose the change in TFP into technical change and efficiency change. The Malmquist TFP index measures the change in outputs $(y)$ with respect to change in the inputs $(x)$. To measure productivity growth, we consider two periods, $t$ and $t+1$. In period $t$, a bank produces output $y^{t}$ by using input $x^{t}$, whereas in period $t+1$, quantities are $y^{t+1}$ and $x^{t+1}$, respectively. To avoid an arbitrary choice of reference technology, the input-oriented Malmquist productivity index is defined as the geometric mean of $M$ (see Fare et al. 1994):

$$
M\left(x^{t+1}, y^{t+1}, x^{t}, y^{t}\right)=\left[\frac{D^{t}\left(x^{t}, y^{t}\right)}{D^{t}\left(x^{t+1}, y^{t+1}\right)} \times \frac{D^{t+1}\left(x^{t}, y^{t}\right)}{D^{t+1}\left(x^{t+1}, y^{t+1}\right)}\right]^{0.5},
$$


where $M(\times)$ and $D^{t+1}(\times)$ denotes the Malmquist productivity index and distance from the period $t$ observation to the period $t+1$ technology or efficiency frontier, respectively. A value of $M(\times)$ greater than 1 indicates a TFP growth between periods $t$ and $t+1$; a value less than 1 indicates a deterioration in TFP between periods $t$ and $t+1$ and a value equal to 1 indicates no change in TFP.

The Malmquist index can be decomposed into efficiency change, which is how much closer a bank gets to the efficient frontier (catching-up effect) and technical change, which is how much the benchmark production frontier shifts at each bank's observed input mix (technical innovation), components to analyze the sources of TFP change. Following Fare et al. (1994), this decomposition can be denoted as in Equation A.2:

$$
M\left(x^{t+1}, y^{t+1}, x^{t}, y^{t}\right)=\frac{D^{t}\left(x^{t}, y^{t}\right)}{D^{t+1}\left(x^{t+1}, y^{t+1}\right)}\left[\frac{D^{t+1}\left(x^{t}, y^{t}\right)}{D^{t}\left(x^{t}, y^{t}\right)} \times \frac{D^{t+1}\left(x^{t+1}, y^{t+1}\right)}{D^{t}\left(x^{t+1}, y^{t+1}\right)}\right]^{0.5} .
$$

The ratio outside the brackets is referred to as technical efficiency change (TE) The term in brackets to the power 0.5 indicates the technical change (TC) between periods $t$ and $t+1$ (under constant returns to scale, CRS, technology). It reflects the improvement or deterioration of best practice banks. Both components can be greater than, less than or equal to 1 similar to the Malmquist TFP index. In Equation A.1, $x^{t}$ and $y^{t}$ denote vector of inputs (they are total interest expenses, personnel expenses and other operating expenses) and outputs (they are total customer loans and other earning assets), respectively.

As shown above, if the production technology exhibits CRS there are only two sources of productivity growth: technical efficiency change and technical change. However, if the production technology exhibits variable returns to scale, VRS, there are two additional sources of productivity growth: pure technical efficiency change and scale efficiency change. Hence, the efficiency change indicated in Equation A.2 can be decomposed into pure efficiency change (PE) and scale efficiency (SE) change as follows:

$$
\begin{gathered}
\mathrm{PE}=\frac{D^{t}\left(x^{t}, y^{t} \mid \mathrm{VRS}\right)}{D^{t+1}\left(x^{t+1}, y^{t+1} \mid \mathrm{VRS}\right)} \\
\mathrm{SE}=\left[\frac{D^{t}\left(x^{t}, y^{t}\right)}{D^{t}\left(x^{t}, y^{t} \mid \mathrm{VRS}\right)} \cdot \frac{D^{t+1}\left(x^{t+1}, y^{t+1} \mid \mathrm{VRS}\right)}{D^{t+1}\left(x^{t+1}, y^{t+1}\right)}\right]^{0.5},
\end{gathered}
$$

where $D(\bullet \mid$ VRS $)$ represents distance functions calculated under the assumption of variable returns to scale. Improvements in scale efficiency occur if SE $>1$. 
Adnan KASMAN is a Professor of Economics at Dokuz Eylul University. He received his Ph.D. degree in economics from Vanderbilt University in 1999. His primary research interests include financial institutions and markets, industrial organization, and econometrics.

Saadet KASMAN is a Professor of Economics at Dokuz Eylul University. She received her Ph.D. degree in economics from Vanderbilt University in 2002. Her primary research interests include money and banking issues, financial economics and macroeconomics.

Duygu AYHAN is an Assistant Professor of Economics at Dokuz Eylul University. She received her Ph.D. in economics from Dokuz Eylul University, Izmir, Turkey in 2008. Her primary research interests include macroeconomics, financial markets and institutions, emerging markets.

Erdost TORUN is a Research Assistant in the Department of International Business and Trade at Dokuz Eylul University. He received his Ph.D. in finance from Dokuz Eylul University, Izmir, Turkey in 2012. His primary research interests include financial markets, statistics and data analysis. 